\title{
Hydroxycinnamic derivatives content in plant organs linked to harvest time of Salvia officinalis L. cv. 'Krajová' Obsah hydroxyškoricových derivátov $\mathrm{v}$ rastlinných orgánoch Salvia officinalis L. cv. 'Krajová' v závislosti od termínu zberu
}

${ }^{1}$ Comenius University in Bratislava, Faculty of Pharmacy, Department of Pharmacognosy and Botany, Bratislava, Slovak Republic
Tekel'ová D. ${ }^{1, \square}$, Tóth J. ${ }^{\prime}$, Czigle Sz. ${ }^{1}$, Koutsoulas A. ${ }^{1}$

${ }^{1}$ Univerzita Komenského v Bratislave,

Farmaceutická fakulta, Katedra farmakognózie

a botaniky, Bratislava, Slovenská republika

Received January 29, 2015, accepted March 3, 2015

Abstract Salvia officinalis L. (sage) is an important essential oil containing Mediterranean medicinal plant that is commonly cultivated for pharmaceutical uses. In addition to essential oil, other compounds participate on the biological effects of sage, mainly diterpenes, triterpenes and phenolic compounds of the hydroxycinnamic and flavonoid types. Sage essential oil content is known to differ in plant parts, and to be influenced by plant phenophase, climatic and edaphic conditions. This work deals with the study of total hydroxycinnamic derivatives (THD), and specifically rosmarinic acid (RA), content variation in different aerial parts of sage linked to different harvest times. Dry sage leaves (Salviae officinalis folium) THD content was quantified using a pharmacopoeial method, and varied between $3.06 \%$ and $3.52 \%$ in different harvest times, with maxima in youngest plant shoot leaves and newly-grown shoots in September. Sage stems showed similar THD content variations when linked to harvest times, however with lower percentage, $1.33-3.04 \%$. Rosmarinic acid variability showed the same trends, its content ranged between $0.76 \%$ and $1.65 \%$ in leaves, and between $0.19 \%$ and $0.83 \%$ in stems, respectively. Highest percentages of both THD and RA were found in top leaves, lowest in leaves from the middle of the stem. When linked to plant phenophase, the content of THD and RA decreased at flowering time.

Slovak Salvia officinalis L. (šalvia lekárska) je významnou silicovou liečivou rastlinou domácou v oblasti Stredomoria, pre farmaceutické abstract účely sa pestuje. Okrem silice sa na biologickom účinku rastliny podielajú hlavne diterpény, triterpény a fenolové látky typu hydroxyškoricových derivátov a flavonoidov. Je známe, že obsah a kvalita silice v šalvii kolíše v závislosti od rastlinnej časti, vývinovej fázy, klimatických a pôdnych podmienok. V našej práci sme sledovali kolísanie obsahu celkových hydroxyškoricových derivátov (THD) a samotnej kyseliny rozmarínovej (RA) v nadzemných častiach šalvie lekárskej v rôznych termínoch zberu. Obsah THD v suchých listoch (Salviae officinalis folium) stanovený liekopisnou metódou kolísal v jednotlivých termínoch zberu od $3,06 \%$ do 3,52 \%, najvyšší bol v listoch z výhonkov najmladších rastlín a z novonarastených výhonkov v septembri. Podobné kolísanie obsahu THD v jednotlivých zberoch bolo aj v stonkách, tie však obsahovali len 1,33-3,04\%. Rovnakú variabilitu obsahu sme zaznamenali pri kyseline rozmarínovej, jej obsah v listoch kolísal od 0,76\% do 1,65 \% a v stonkách od 0,19\% do 0,83\%. Najvyšší obsah THD a RA bol vo vrcholových listoch, najnižší v listoch umiestnených v strede stonky. Počas kvitnutia rastliny sa obsah THD a RA v listoch znížil.

Keywords Salvia officinalis-THD-rosmarinic acid-plant organ-harvest time

Klúčové Salvia officinalis - THD - kyselina rozmarínová - rastlinná čast' - termín zberu slová:

\section{INTRODUCTION}

Salvia officinalis L. (sage) is a common aromatic plant of the Lamiaceae family, widely cultivated for its medicinal and culinary purposes. Sage shows various biological activities and medicinal properties: antioxidant, antibacterial, antifungal, anti-inflammatory, antispasmodic, astringent and antihidrotic (Bouaziz et al., 2009; Martins et al., 2015; Lu \& Foo, 2001; Baricevic et al., 2001; Khan et al., 2011; British Herbal Compendium, 2006). The predominant medicinally valuable compounds are monoterpenes in essential oil (a- and $\beta$-thujones, 1,8-cineol, camphor), diterpenes (carnosic

*E-mail: tekelova@fpharm.uniba.sk

( ) Acta Facultatis Pharmaceuticae Universitatis Comenianae 
acid, carnosol), triterpenes (ursolic and oleanolic acids) and phenolics - phenolic acids (especially caffeic acid and their depside forms, e.g. rosmarinic acid) and flavonoids (luteoline and apigenine derivatives). The main antioxidative effect of Salvia officinalis was reported to relate to the presence of carnosic acid, carnosol, and hydroxycinnamic derivatives, especially rosmarinic acid (Cuvelier et al., 1996). Hydroxycinnamic derivatives are sometimes described as "Lamiaceae or Labiatae tannins" since they may be adsorbed by hide powder to some extent in methods for the determination of tannins in herbal drugs. However, they are not genuine tannins (British Herbal Compendium, 2006).

Pharmacopoeial assays usually require the quantification of essential oil in herbal drugs originating from Lamiaceae plant species (more precisely from the Nepetoideae subfamily species). Sometimes the total hydroxycinnamic derivatives or specifically rosmarinic acid quantification is required (as in Rosmarini folium, Melissae folium). For Salviae officinalis folium, the European Pharmacopoeia ( $8^{\text {th }}$ Edition) includes the essential oil assay (Ph. Eur. 8, 2014).

The content and composition of sage essential oil has been studied extensively in previous years. Changes in its content due to external and internal influences, e.g. locality, climatic conditions, plant phenophase, as well as content differences in respective plant parts are reported in previous studies (Grella \& Picci, 1988; Tekel'ová, 1993; Tekel’ová \& Havassy, 1993; Rasmussen et al., 1971; Tekelová \& Felklová, 1993; Tekel'ová et al., 1994). Contemporary research also focuses on sage phenolic compounds that show antioxidant activity. Factors influencing their accumulation in respective plant organs and links to e.g. plant phenophase have not yet been studied well so far. This inspired the present study that quantifies total hydroxycinnamic derivatives and rosmarinic acid in sage leaf and stem samples from different harvest times. Individual opposite leaf pairs have been studied as well.

\section{MATERIAL AND METHODS}

\subsection{Plant material}

Salvia officinalis L. cv. 'Krajová' plants were grown in climate conditions of Southwest Slovakia, in the Medicinal Plants Garden, Faculty of Pharmacy, Comenius University in Bratislava. A 3-years-old culture was planted on a light sand-loam soil in a sunny location. Non-flowering tops were harvested at 3 different times of year: at the end of May and in mid-June in the vegetative development phase, and in July in the flowering phase, respectively. Subsequently, a second harvest was carried out in September (of plants first harvested in June). Harvests were generally carried out in the afternoon of sunny days. Plant shoots were dried at room temperature. Dry shoots were separated into: individual opposite leaf pairs, side branches, and stems. These fractions were stored separately in paper sachets at room temperature. Voucher specimens were deposited at the Herbarium, Department of Pharmacognosy and Botany, Faculty of Pharmacy, Comenius University in Bratislava.

\subsection{Biological evaluation and secondary metabolites determination}

Phenolic compounds were quantified both in dry leaves (average sample), and in individual leaf pairs samples, as well as in stems. Biological evaluation was carried out on 10 sample shoots. Chemical analyses were carried out on average samples gained from 100 shoots. Measurements were performed in triplicate.

\subsubsection{Total hydroxycinnamic derivatives (THD) (Arnow's spectrophotometric assay)}

THD content was quantified using a spectrophotometric method that employs Arnow's reagent according to the European Pharmacopoeia (Ph. Eur. 8, 2014). Two extraction solvents, ethanol (50\% V/V) and methanol, were used, respectively. Measuring conditions: $505 \mathrm{~nm}$; spectrophotometer Genesys 6 (Thermo Electron Corporation, UK). THD percentage was calculated with reference to the dried drug and expressed as rosmarinic acid content.

\subsubsection{Rosmarinic acid (RA) (HPLC assay)}

Rosmarinic acid content was quantified using a previously published HPLC method (Tóth et al., 2003). The plant materials were extracted with methanol in Soxhlet's apparatus (3 hours). Measuring conditions: HPLC set: ECOM (Czech Republic, gradient elution: methanol and orthophosphoric acid ( $\mathrm{pH}$ 2.5), column: LiChrospher 100 (RP-18(e), $5 \mu \mathrm{m}$, $125 \times 4 \mathrm{~mm}$ ), liquid-liquid pre-separation, UVD: $320 \mathrm{~nm}$. RA percentage was calculated using the external standard method (rosmarinic acid, Aldrich, USA) based on peak area, with reference to the dried drug.

\section{RESULTS AND DISCUSSION}

Sage (Salvia officinalis L.) is native to the Mediterranean area, but can be successfully cultivated in Central European climatic conditions, including Slovak Republic. Our previous cultivation experience with the domestic cultivar 'Krajová' shows that several harvests in the course of one year are possible (Tekelová, 1993). Both sage leaf and whole herb constitute herbal drugs of pharmacopoeial quality. The Pharmacopoea Bohemoslovaca listed a herb monograph Herba salviae (PhBs IV, 1987). The currently valid monograph of the European Pharmacopoeia describes the leaf - Salviae officinalis folium (Ph. Eur. 8, 2014). The recommended time for leaf harvest lies in the phenophase before flowering, or at the beginning of flowering at latest (May/July), as leaf essential 


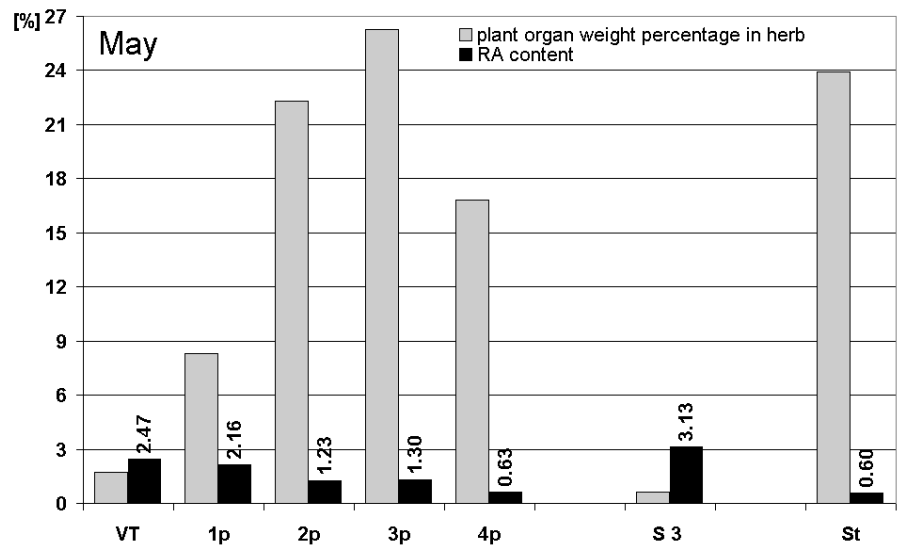

Figure 1. Salvia officinalis L. CV. 'Krajová' - May harvest - plant organ weight percentage in herb compared to RA content [\%]. RA content - rosmarinic acid content ([\%] in dry aerial plant organs), VT - vegetative top, 1p - 1st opposite leaf pair (2p to $4 p$-subsequent leaf pairs), S 3 - side branches (length 0.5 to $3 \mathrm{~cm}$ ), St - stem. Values are presented as average value.

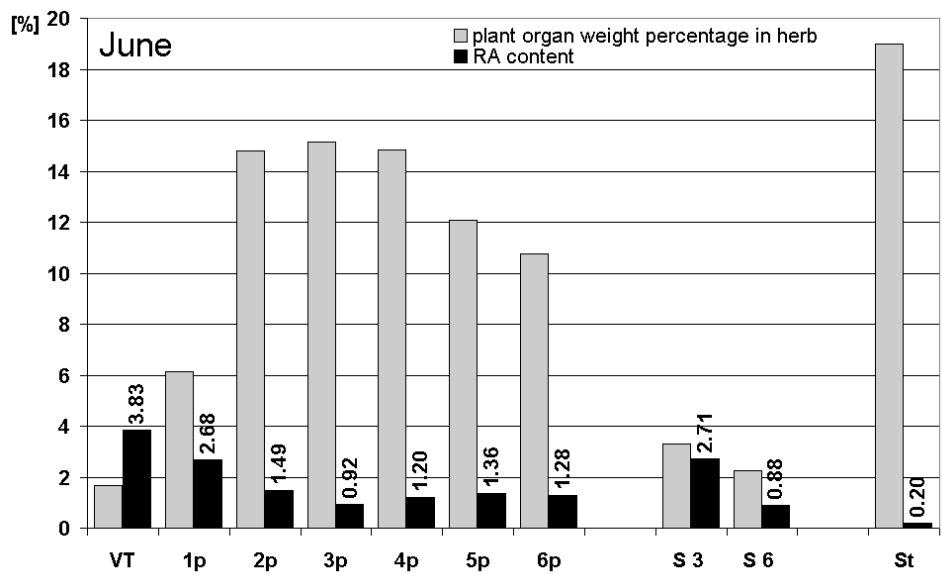

Figure 2. Salvia officinalis L. Cv. 'Krajová' - June harvest - plant organ weight percentage in herb compared to RA content [\%]. RA content - rosmarinic acid content ([\%] in dry aerial plant organs), VT - vegetative top, $1 p$ - 1 st opposite leaf pair (2p to $6 p$ - subsequent leaf pairs), $S$ - side branches of different length (S $3-0.5$ to $3 \mathrm{~cm}, S 6-3.5$ to $6 \mathrm{~cm}), S t-s t e m$. Values are presented as average value.

oil content decreases during the flowering phase (June/ August) (Heeger, 1956). Another important reason to carry out an earlier harvest in our climatic conditions is the risk of plant culture frost damage in winter, after the first harvest has been carried out at the flowering phase, and the subsequent second harvest was shifted to later autumn (Heeger, 1956).

This work deals with the total hydroxycinnamic derivatives (THD) and rosmarinic acid (RA) content quantification in aerial parts of the domestic cultivar Salvia officinalis $L$. 'Krajová' in the course of one vegetation year. Whole nonflowering tops were harvested. The first harvest was carried out at three different times of the year: at the end of May and in mid-June in the vegetative development phase, and in July in the flowering phase, respectively. Subsequently, a second harvest was carried out in September (of plants first harvested in June). Shoots from the May and June harvests grew 4, and 6 opposite leaf pairs in average, respectively. Longest leaves were $7-8 \mathrm{~cm}$ long (without petiole). Only non-flowering tops were cut of flowering plants in July. These shoots showed 11 opposite leaf pairs in average; the longest leaf was $8.6 \mathrm{~cm}$ long (Table 1). Leaves placed on the middle part of the stem represented the largest weight portion of the whole leaf samples. Stems counted for $17.5-28 \%$ of whole herb weight (Fig. 1 - 4).

A spectrophotometric pharmacopoeial method (Ph. Eur. 8 , 2014) was employed for the quantification of total hydroxycinnamic derivatives (THD), as published in the Rosmarini folium monograph assay. The Salviae officinalis folium monograph requires the assay for essential oil instead of the THD assay. The extraction solvent for the pharmacopoeial THD assay is ethanol (50\% V/V), whereas methanol has often been employed for the rosmarinic acid (RA) extraction (Gracza \& Ruff, 1984; Baskan et al., 2007). Water-ethanolic leaf extracts (50\% V/V) of whole shoots samples (Salviae officinalis folium) showed small variations only in THD content in the course of one year: from $3.06 \%$ to $3.52 \%$, with maxima in May and September samples. Stems of all first harvests contained $1.33-1.54 \%$ THD only. 
Table 1. Salvia officinalis L. cv. 'Krajová' - leaf length, and THD quantification [\%] in leaf pairs linked to harvest time and extraction solvent

\begin{tabular}{|c|c|c|c|c|c|c|c|c|c|c|c|c|}
\hline & \multicolumn{6}{|c|}{ Vegetative phase } & \multirow{2}{*}{\multicolumn{3}{|c|}{$\begin{array}{c}\text { Flowering phase } \\
\text { July }\end{array}$}} & \multirow{2}{*}{\multicolumn{3}{|c|}{$\begin{array}{c}\text { Second harvest } \\
\text { September }\end{array}$}} \\
\hline & \multicolumn{3}{|c|}{ May } & \multicolumn{3}{|c|}{ June } & & & & & & \\
\hline & \multirow{2}{*}{$\begin{array}{l}\text { Leaf } \\
\text { length } \\
\text { [cm] }\end{array}$} & \multicolumn{2}{|c|}{ THD [\%] } & \multirow{2}{*}{$\begin{array}{l}\text { Leaf } \\
\text { length } \\
\text { [cm] }\end{array}$} & \multicolumn{2}{|c|}{ THD [\%] } & \multirow{2}{*}{$\begin{array}{l}\text { Leaf } \\
\text { length } \\
\text { [cm] }\end{array}$} & \multicolumn{2}{|c|}{ THD [\%] } & \multirow{2}{*}{$\begin{array}{l}\text { Leaf } \\
\text { length } \\
{[\mathrm{cm}]}\end{array}$} & \multicolumn{2}{|c|}{ THD [\%] } \\
\hline & & $\begin{array}{c}50 \% \\
\text { EtOH }\end{array}$ & $\mathrm{MeOH}$ & & $\begin{array}{c}50 \% \\
\text { EtOH }\end{array}$ & МeOH & & $\begin{array}{c}50 \% \\
\text { EtOH }\end{array}$ & $\mathrm{MeOH}$ & & $\begin{array}{c}50 \% \\
\text { EtOH }\end{array}$ & $\mathrm{MeOH}$ \\
\hline VT & & $\begin{array}{l}6.21 \\
0.60\end{array}$ & $\begin{array}{l}\mathbf{4 . 8 1} \\
0.39\end{array}$ & & $\begin{array}{l}\mathbf{5 . 1 4} \\
0.44\end{array}$ & $\begin{array}{l}\mathbf{5 . 7 0} \\
0.37\end{array}$ & & $\begin{array}{l}\mathbf{6 . 0 9} \\
1.63\end{array}$ & $\begin{array}{l}\mathbf{6 . 0 3} \\
0.36\end{array}$ & & $\begin{array}{l}\mathbf{4 . 7 0} \\
0.45\end{array}$ & $\begin{array}{l}4.96 \\
0.26\end{array}$ \\
\hline $1 p$ & $\begin{array}{l}3.4 \\
0.5\end{array}$ & $\begin{array}{l}\mathbf{2 . 4 4} \\
0.17\end{array}$ & $\begin{array}{l}\mathbf{2 . 6 5} \\
0.27\end{array}$ & $\begin{array}{l}3.9 \\
0.9\end{array}$ & $\begin{array}{l}3.38 \\
0.29\end{array}$ & $\begin{array}{l}3.51 \\
0.29\end{array}$ & $\begin{array}{l}3.4 \\
0.7\end{array}$ & $\begin{array}{l}\mathbf{4 . 5 0} \\
0.20\end{array}$ & $\begin{array}{l}3.79 \\
0.13\end{array}$ & $\begin{array}{l}3.1 \\
0.6\end{array}$ & $\begin{array}{l}3.49 \\
0.38\end{array}$ & $\begin{array}{l}3.38 \\
0.19\end{array}$ \\
\hline $2 p$ & $\begin{array}{l}5.9 \\
1.1\end{array}$ & $\begin{array}{l}\mathbf{2 . 5 7} \\
0.31\end{array}$ & $\begin{array}{l}1.96 \\
0.13\end{array}$ & $\begin{array}{l}6.5 \\
1.1\end{array}$ & $\begin{array}{l}2.76 \\
0.19\end{array}$ & $\begin{array}{l}\mathbf{2 . 0 2} \\
0.21\end{array}$ & $\begin{array}{l}4.4 \\
0.4\end{array}$ & $\begin{array}{l}3.06 \\
0.19\end{array}$ & $\begin{array}{l}2.14 \\
0.16\end{array}$ & $\begin{array}{l}4.9 \\
0.4\end{array}$ & $\begin{array}{l}\mathbf{2 . 7 1} \\
0.24\end{array}$ & $\begin{array}{c}2.6 \\
0.15\end{array}$ \\
\hline $3 p$ & $\begin{array}{l}7.2 \\
1.2\end{array}$ & $\begin{array}{l}3.05 \\
0.34\end{array}$ & $\begin{array}{l}\mathbf{2 . 2 4} \\
0.20\end{array}$ & $\begin{array}{l}7.7 \\
0.6\end{array}$ & $\begin{array}{l}\mathbf{2 . 2 7} \\
0.31\end{array}$ & $\begin{array}{l}1.70 \\
0.07\end{array}$ & $\begin{array}{l}\mathbf{5 . 8} \\
0.5\end{array}$ & $\begin{array}{l}\mathbf{2 . 3 4} \\
0.45\end{array}$ & $\begin{array}{l}1.38 \\
0.26\end{array}$ & $\begin{array}{l}5.8 \\
0.5\end{array}$ & $\begin{array}{l}\mathbf{2 . 9 4} \\
0.28\end{array}$ & $\begin{array}{l}2.56 \\
0.13\end{array}$ \\
\hline $4 p$ & $\begin{array}{l}6.9 \\
1.5\end{array}$ & $\begin{array}{l}\mathbf{1 . 4 5} \\
0.15\end{array}$ & $\begin{array}{l}1.30 \\
0.14\end{array}$ & $\begin{array}{l}7.9 \\
1.0\end{array}$ & $\begin{array}{l}\mathbf{2 . 9 5} \\
0.24\end{array}$ & $\begin{array}{l}2.38 \\
0.13\end{array}$ & $\begin{array}{l}6.5 \\
0.6\end{array}$ & $\begin{array}{l}\mathbf{2 . 2 7} \\
0.13\end{array}$ & $\begin{array}{l}1.19 \\
0.27\end{array}$ & $\begin{array}{l}5.9 \\
0.7\end{array}$ & $\begin{array}{l}\mathbf{2 . 9 8} \\
0.27\end{array}$ & $\begin{array}{l}\mathbf{1 . 9 9} \\
0.13\end{array}$ \\
\hline $5 p$ & & & & $\begin{array}{l}7.8 \\
0.8\end{array}$ & $\begin{array}{l}3.35 \\
0.16\end{array}$ & $\begin{array}{l}2.31 \\
0.26\end{array}$ & $\begin{array}{l}6.8 \\
0.9\end{array}$ & $\begin{array}{l}\mathbf{2 . 3 2} \\
0.33\end{array}$ & $\begin{array}{l}1.21 \\
0.09\end{array}$ & $\begin{array}{l}5.5 \\
0.7\end{array}$ & $\begin{array}{l}\mathbf{3 . 0 8} \\
0.23\end{array}$ & $\begin{array}{l}2.41 \\
0.14\end{array}$ \\
\hline $6 p$ & & & & $\begin{array}{l}7.3 \\
1.3\end{array}$ & $\begin{array}{l}3.03 \\
0.12\end{array}$ & $\begin{array}{l}1.98 \\
0.10\end{array}$ & $\begin{array}{l}7.1 \\
0.9\end{array}$ & $\begin{array}{l}\mathbf{2 . 2 2} \\
0.31\end{array}$ & $\begin{array}{l}\mathbf{0 . 8 9} \\
0.06\end{array}$ & $\begin{array}{l}5.2 \\
0.7\end{array}$ & $\begin{array}{l}\mathbf{3 . 5 1} \\
0.35\end{array}$ & $\begin{array}{l}\mathbf{2 . 7 5} \\
0.12\end{array}$ \\
\hline $7 p$ & & & & & & & $\begin{array}{l}7.5 \\
0.8\end{array}$ & $\begin{array}{l}\mathbf{2 . 4 9} \\
0.35\end{array}$ & $\begin{array}{l}1.00 \\
0.02\end{array}$ & $\begin{array}{l}\mathbf{4 . 4} \\
0.5\end{array}$ & $\begin{array}{l}\mathbf{3 . 7 5} \\
0.31\end{array}$ & $\begin{array}{l}2.37 \\
0.11\end{array}$ \\
\hline $8 p$ & & & & & & & $\begin{array}{l}\mathbf{8 . 2} \\
0.9\end{array}$ & $\begin{array}{l}\mathbf{2 . 6 2} \\
0.10\end{array}$ & $\begin{array}{l}\mathbf{1 . 4 7} \\
0.12\end{array}$ & & & \\
\hline $9 p$ & & & & & & & $\begin{array}{l}8.6 \\
0.9\end{array}$ & $\begin{array}{l}2.73 \\
0.88\end{array}$ & $\begin{array}{l}1.60 \\
0.14\end{array}$ & & & \\
\hline $10 p$ & & & & & & & $\begin{array}{l}8.2 \\
0.2\end{array}$ & $\begin{array}{l}3.15 \\
0.83\end{array}$ & $\begin{array}{l}\mathbf{1 . 5 3} \\
0.15\end{array}$ & & & \\
\hline $11 p$ & & & & & & & $\begin{array}{l}8.4 \\
0.1\end{array}$ & $\begin{array}{l}\mathbf{2 . 5 9} \\
0.15\end{array}$ & $\begin{array}{l}\mathbf{1 . 1 9} \\
0.10\end{array}$ & & & \\
\hline S 3 & & $\begin{array}{l}\mathbf{3 . 5 8} \\
0.33\end{array}$ & $\begin{array}{l}3.43 \\
0.30\end{array}$ & & $\begin{array}{l}3.30 \\
0.21\end{array}$ & $\begin{array}{l}3.80 \\
0.24\end{array}$ & & $\begin{array}{l}3.29 \\
0.30\end{array}$ & $\begin{array}{l}3.00 \\
0.29\end{array}$ & & $\begin{array}{l}3.91 \\
0.28\end{array}$ & $\begin{array}{l}3.88 \\
0.19\end{array}$ \\
\hline S 6 & & & & & $\begin{array}{c}2.96 \\
0.18\end{array}$ & $\begin{array}{l}3.93 \\
0.29\end{array}$ & & $\begin{array}{l}\mathbf{3 . 5 0} \\
0.27\end{array}$ & $\begin{array}{l}\mathbf{2 . 0 7} \\
0.17\end{array}$ & & $\begin{array}{l}3.22 \\
0.15\end{array}$ & $\begin{array}{l}3.37 \\
0.23\end{array}$ \\
\hline S 10 & & & & & & & & $\begin{array}{l}2.93 \\
0.19\end{array}$ & $\begin{array}{l}\mathbf{1 . 8 5} \\
0.10\end{array}$ & & & \\
\hline
\end{tabular}

THD - total hydroxycinnamic derivatives content expressed as rosmarinic acid ([\%] in dry leaves), VT - vegatative top, $1 p-1^{\text {st }}$ opposite leaf pair ( $2 p$ to $11 p$-subsequent leaf pairs), $S$-side branches of different length ( $3-0.5$ to $3 \mathrm{~cm}, S 6-3.5$ to $6 \mathrm{~cm}, S 10-6.5$ to $10 \mathrm{~cm}$ ), $50 \% \mathrm{EtOH}$ - ethanol ( $50 \% \mathrm{~V} / \mathrm{V})$ extract, $\mathrm{MeOH}$ - methanol extract. Values are presented as average value (bold) \pm standard deviation. 


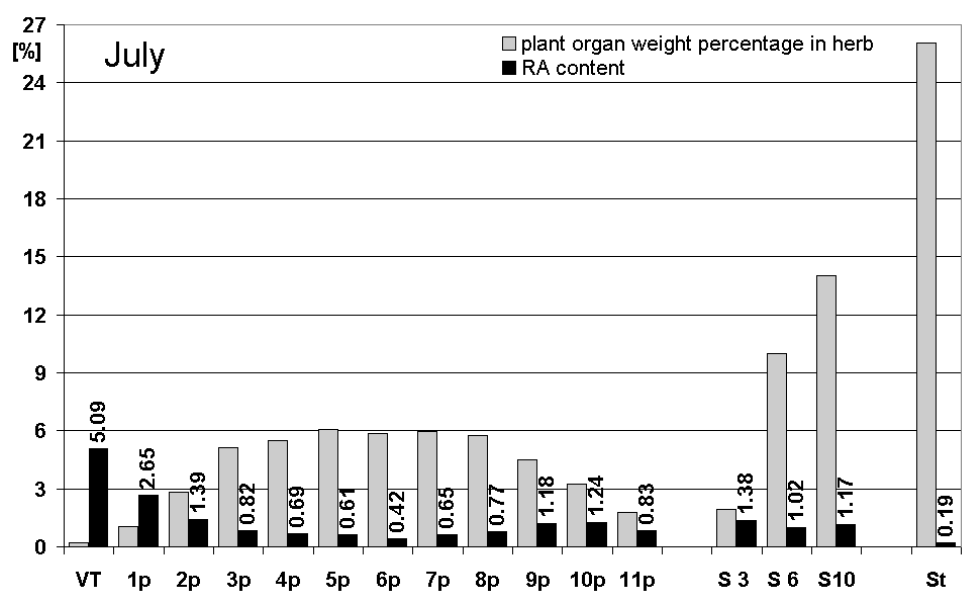

Figure 3. Salvia officinalis L. cv. 'Krajová' - July harvest - plant organ weight percentage in herb compared to RA content [\%]. RA content - rosmarinic acid content ([\%] in dry aerial plant organs), VT - vegetative top, $1 p$ - 1st opposite leaf pair (2p to $11 p$ - subsequent leaf pairs), $S$ - side branches of different length ( $3-0.5$ to $3 \mathrm{~cm}, S 6-3.5$ to $6 \mathrm{~cm}, S 10-6.5$ to $10 \mathrm{~cm}$ ), St - stem. Values are presented as average value.

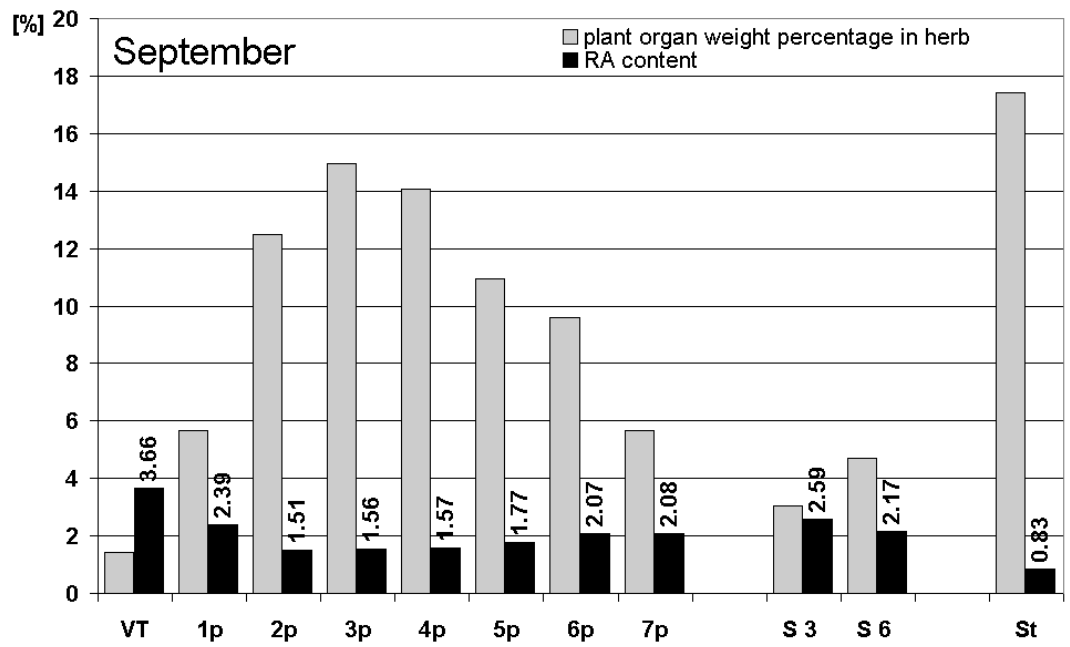

Figure 4. Salvia officinalis L. CV. 'Krajová' - September (second) harvest - plant organ weight percentage in herb compared to RA content [\%]. RA content - rosmarinic acid content ([\%] in dry aerial plant organs), VT - vegetative top, 1p - 1st opposite leafpair (2p to $7 p$-subsequent leaf pairs), $S$-side branches of different length ( $\mathrm{S} 3-0.5$ to $3 \mathrm{~cm}, \mathrm{~S} 6-3.5$ to $6 \mathrm{~cm}$ ), $S t-s t e m$. Values are presented as average value.

Stems of the second harvest increased their THD content to percentages comparable to leaf samples, on the contrary. This applies mostly to the fleshy top part of the stems. Methanolic extracts showed THD contents lower by about $1 / 4$ compared to the water-ethanolic leaf extracts (Table 2). Common sage THD percentages have been reported to be in the range of $3.5 \%$ (Lamaison et al., 1990). Our domestic cultivar 'Krajová' shows slightly lower percentages that but still obey the pharmacopoeial criteria of other Lamiaceae herbal drugs monographs, e.g. Rosmarini folium: min. 3 \% (Ph. Eur. 8, 2014). Rosmarinic acid (RA) quantification was carried out using a previously published method (Tóth et al., 2003). Leaves and stems RA percentages showed very similar trends compared to the THD content, with maxima in youngest-grown shoots (May and September): leaves $0.76-1.65 \%$, and stems 0.19 - $0.83 \%$ of RA, respectively. The RA leaf content showed a marked decrease during the flowering phenophase (July). Other authors have reported higher September RA percentages as well (Areias et al., 2000). Reference values for sage leaf RA content range from $0.2 \%$ to $1.4 \%$ (Janicsák et al., 1999; Wang et al., 2004). European Pharmacopoeia's Lamiaceae herbal drugs monographs HPLC assays, e.g. Melissae folium, require RA contents not lower than $1.0 \%$ (Ph. Eur. 8, 2014). Stems show generally low RA content, except for fleshy top parts, which in some cases showed RA contents even exceeding leaf RA percentages (Table 2). 
Table 2. Salvia officinalis L. cv. 'Krajová' - THD and RA quantification [\%] in leaf and stem samples linked to harvest time and extraction solvent

\begin{tabular}{|c|c|c|c|c|c|c|c|}
\hline & & & \multirow{2}{*}{ Extract } & \multicolumn{2}{|c|}{ Vegetative phase } & \multirow{2}{*}{$\begin{array}{c}\text { Flowering phase } \\
\text { July }\end{array}$} & \multirow{2}{*}{$\begin{array}{c}\text { Second harvest } \\
\text { September }\end{array}$} \\
\hline & & & & May & June & & \\
\hline \multirow{3}{*}{\multicolumn{2}{|c|}{ Leaf }} & \multirow{2}{*}{ THD } & $50 \%$ EtOH & $\begin{array}{l}\mathbf{3 . 5 2} \\
0.25\end{array}$ & $\begin{array}{l}3.26 \\
0.33\end{array}$ & $\begin{array}{l}3.06 \\
0.31\end{array}$ & $\begin{array}{l}3.33 \\
0.29\end{array}$ \\
\hline & & & $\mathrm{MeOH}$ & $\begin{array}{l}\mathbf{2 . 7 7} \\
0.31\end{array}$ & $\begin{array}{l}\mathbf{2 . 5 7} \\
0.21\end{array}$ & $\begin{array}{l}\mathbf{1 . 3 6} \\
0.11\end{array}$ & $\begin{array}{l}2.41 \\
0.17\end{array}$ \\
\hline & & RA & MeOH & $\begin{array}{l}\mathbf{1 . 6 5} \\
0.12\end{array}$ & $\begin{array}{l}1.31 \\
0.04\end{array}$ & $\begin{array}{l}\mathbf{0 . 7 6} \\
0.08\end{array}$ & $\begin{array}{l}\mathbf{1 . 5 7} \\
0.12\end{array}$ \\
\hline \multirow{6}{*}{ Stem } & \multirow{3}{*}{ Whole } & \multirow{2}{*}{ THD } & $50 \%$ EtOH & $\begin{array}{l}1.46 \\
0.13\end{array}$ & $\begin{array}{l}1.33 \\
0.10\end{array}$ & $\begin{array}{l}1.54 \\
0.11\end{array}$ & $\begin{array}{l}3.04 \\
0.23\end{array}$ \\
\hline & & & $\mathrm{MeOH}$ & $\begin{array}{l}\mathbf{1 . 1 0} \\
0.10\end{array}$ & $\begin{array}{l}\mathbf{0 . 5 1} \\
0.26\end{array}$ & $\begin{array}{l}\mathbf{0 . 6 2} \\
0.25\end{array}$ & $\begin{array}{l}2.39 \\
0.15\end{array}$ \\
\hline & & RA & MeOH & $\begin{array}{l}\mathbf{0 . 6 0} \\
0.04 \\
\end{array}$ & $\begin{array}{l}0.20 \\
0.03\end{array}$ & $\begin{array}{l}\mathbf{0 . 1 9} \\
0.03\end{array}$ & $\begin{array}{l}\mathbf{0 . 8 3} \\
0.14 \\
\end{array}$ \\
\hline & \multirow{3}{*}{ Top part } & \multirow{2}{*}{ THD } & $50 \%$ EtOH & $\begin{array}{l}\mathbf{2 . 1 7} \\
0.31 \\
\end{array}$ & $\begin{array}{l}1.84 \\
0.11 \\
\end{array}$ & $\begin{array}{l}1.78 \\
0.16 \\
\end{array}$ & $\begin{array}{l}3.36 \\
0.19 \\
\end{array}$ \\
\hline & & & MeOH & $\begin{array}{l}\mathbf{2 . 4 8} \\
0.23\end{array}$ & $\begin{array}{l}1.66 \\
0.13\end{array}$ & $\begin{array}{l}2.05 \\
0.17\end{array}$ & $\begin{array}{l}\mathbf{2 . 8 3} \\
0.21\end{array}$ \\
\hline & & RA & $\mathrm{MeOH}$ & $\begin{array}{l}1.70 \\
0.14\end{array}$ & $\begin{array}{l}\mathbf{0 . 8 9} \\
0.09\end{array}$ & $\begin{array}{l}\mathbf{0 . 6 9} \\
0.05\end{array}$ & $\begin{array}{l}1.84 \\
0.22\end{array}$ \\
\hline
\end{tabular}

THD - total hydroxycinnamic derivatives content expressed as rosmarinic acid ([\%] in dry leaves), RA - rosmarinic acid content ([\%] in dry leaves), $50 \% \mathrm{EtOH}$ - ethanol (50\% V/V) extract, $\mathrm{MeOH}$ - methanol extract. Values are presented as average value (bold) \pm standard deviation.

Differences in THD and RA contents observed in sage whole shoot leaf samples (Salviae officinalis folium) are notably influenced by the content of these active compounds in the respective leaf pairs. Highest contents of the quantified phenolics are present in top-most shoot parts, and decrease basipetally (Table 2, Fig. $1-4$ ). This illustrates the influence that the cut shoot's number of leaf pairs shows on the overall quality of the herbal drug Salviae officinalis folium. These results complement well findings of some of our previous works with the domestic cultivar Salvia officinalis L 'Krajová' (Tekel'ová \& Felklová, 1993), and confirm that leaves of sage shoots top parts should be the primary harvest source of high-quality herbal drug both from the point of high essential oil and phenolics (THD and RA) contents. First harvest can be carried out as early as in May. Such plant cultures allow even for three harvests in the course of one year (Tekelová, 1993), and such herbal drug (mainly plant material originating from subsequent harvests) shows both sufficient essential oil and phenolics (THD and RA) contents (the Ph. Eur. 8 criterion for the essential oil assay in Salviae officinalis folium is minimum $12 \mathrm{~mL} / \mathrm{kg}$, i.e. $1.2 \% \mathrm{~V} / \mathrm{m}$ ). Leaves of autumn harvests comprise the expectation of higher thujone contents (Tekel'ová \& Havassy, 1993).

\section{CONCLUSION}

Leaves of sage (Salvia officinalis L. cv. 'Krajová') shoots top parts are the best source of high-quality herbal drug both from the point of high essential oil (Tekelová, 1993), and phenolics (THD and RA) contents. The leaf content of the studied phenolics decreases during the flowering phenophase (this is in agreement with previous observations of lower essential oil contents in the flowering phenophase). Both leaves and stems originating in the plant material gained in a subsequent second harvest show higher phenolics (THD and RA) contents.

\section{Acknowledgements}

This study was partially supported by a grant project of the VEGA agency, No. VEGA 2/0044/15. 
[1] Areias J, Valentao P, Andrade PB, Ferreres F, Seabra RM. Flavonoids and phenolic acids of sage: influence of some agricultural factors. J Agric Food Chem 2000;48:6081-6084.

[2] Baricevic D, Sosa S, Della Loggia R. et al. Topical anti-inflammatory activity of Salvia officinalis L. leaves: the relevance of ursolic acid. J Ethnopharmacol. 2001;75:125-132.

[3] Baskan S, Öztekin N., Erim FB. Determination of carnosic acid in sage by capillary electrophoresis. Food Chem 2007;101:17481752.

[4] Bouaziz M, Yangui T, Sayadi S, Dhouib A. Disinfectant properties of essential oils from Salvia officinalis L. cultivated in Tunisia. Food Chem Toxicol 2009,47:2755-2760.

[5] British Herbal Compendium. Vol. 2. Bristol: British Herbal Medicine Association Publications; 2006;339-343.

[6] Cuvelier ME, Berset C, Richard HJ. Antioxidative activity and phenolic composition of pilot-plant and commercial extracts of sage and rosemary. J Am Oil Chem Soc 1996;73:645-652.

[7] European Pharmacopoeia $8^{\text {th }}$ Edition (Ph. Eur. 8), Strasbourg: Council of Europe; 2014;1318,1369,4250.

[8] Gracza L, Ruff P. Rosmarinsäure in Arzneibuchdrogen und ihre HPLC-Bestimmung. Arch Pharm (Weinheim) 1984;317:339-345.

[9] Grella GE, Picci V. Variazioni stagionali dell'olio essenziale di Salvia officinalis. Fitoterapia 1988;59(2):97-102.

[10] Heeger EF. Handbuch des Arznei- und Gewürzpflanzenbaues. Drogengewinnung. Berlin: Deutscher Bauernverlag; 1956;632-633.

[11] Janicsák G, Máthé I, Miklóssy-Vári V, Blunden G. Comparative studies of the rosmarinic and caffeic acid contents of Lamiaceae species. Biochem Syst Ecol 1999;27:733-738.

[12] Khan A, Najeeb-ur-Rehman, AlKharfy KM, Gilani AH. Antidiarrheal and antispasmodic activities of Salvia officinalis are mediated through activation of $\mathrm{K}^{+}$channels. Bangladesh J Pharmacol 2011;6:111-116.

[13] Lamaison JL, Pettitjean-Freytet C, Carnat A. Teneurs en acide rosmarinique, en dérivés hydroxycinnamiques totaux et activité antioxydante ches les Apiacées, les Borraginacées et les Lamiacées médicinales. Ann Pharm Franc 1990;48:103-108.
[14] Lu Y, Foo LY. Antioxidant activities of polyphenols from sage. Food Chem 2001;75:197-202.

[15] Martins N, Barros L, Santos-Buelga C et al. Evaluation of bioactive properties and phenolic compounds in different extracts prepared from Salvia officinalis L. Food Chem 2015;170:378385.

[16] Pharmacopoea Bohemoslovaca, Ed. 4 (PhBs IV). Vol. II. Praha: Avicenum; 1987;416-417.

[17] Rasmussen KE, Rasmussen R, Svendsen AB. Die qualitativen und quantitativen Schwankungen der Einzelkomponenten des ätherischen Öles in den Blättern von Salvia officinalis L. mit der Entwicklung des Blattes. Sci Pharm 1971;39(3):159-167.

[18] Tekel'ová D. Salvia officinalis L. cv. Krajová. II. Kvalita vňatoovej drogy v priebehu ontogenézy. Farm Obzor 1993;62:213-222.

[19] Tekel'ová D, Havassy I. Salvia officinalis L. cv. Krajová. III. Zmeny $v$ kvalite éterického oleja v priebehu ontogenézy. Farm Obzor 1993;62:253-262.

[20] Tekel'ová D, Felklová M. Salvia officinalis L. cv. Krajová. 5. Gehalt an ätherischem Öl, Asche und Hydroxyzimtsäurederivaten in einzelnen Blattinsertionen. Pharmazie 1993;48(12):938-940.

[21] Tekel'ová D, Felklová M, Mártonfi P, Černaj P. Salvia officinalis L. cv. Krajová. 6. Schwankungen des Gehaltes an Komponenten im ätherischen Öl einzelner Krautteile. Pharmazie 1994;49(4):938940.

[22] Tóth J, Mrlianová M, Tekel'ová D, Koreňová M. Rosmarinic acid an important phenolic active compound of lemon balm (Melissa officinalis L.) Acta Fac Pharm Univ Comen 2003;50:139-146.

[23] Wang H, Provan GJ, Heilliwell K. Determination of rosmarinic acid and caffeic acid in aromatic herbs by HPLC. Food Chem 2004;87:307-311. 